\title{
Remembering and Forgetting in Early Second Temple Judah
}

\author{
Ed. by Ehud Ben Zvi and Christoph Levin \\ [Erinnern und Vergessen im Juda der frühen Zeit des zweiten Tempels.]
}

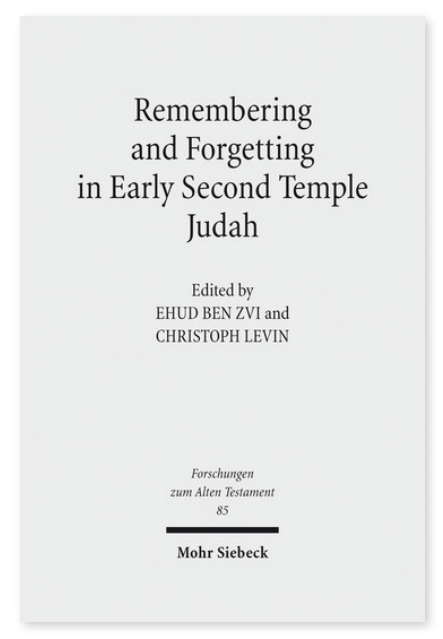

2012. XIV, 360 Seiten. FAT 85

ISBN 978-3-16-152134-8

DOI 10.1628/978-3-16-152134-8

eBook PDF $114,00 €$

ISBN 978-3-16-151909-3

Leinen $114,00 €$
Veröffentlicht auf Englisch.

Dieser Sammelband dokumentiert eine Tagung über Erinnern und Vergessen im frühnachexilischen Juda, die 2011 in München stattfand. Die Vorträge behandeln die Fragestellung unter methodologischem Blickwinkel sowie anhand von Fallbeispielen. Die untersuchten Texte stammen aus der Prophetie, dem Pentateuch, den Geschichtsbüchern, den Psalmen und den Threni. Alle Beispiele verbindet, dass das Erinnern an die Geschichte und der mit ihm verbundene Ausblick auf die Zukunft auf einer bewussten oder unbewussten Auswahl beruht, die ein Vergessen von Vergangenem einschließt.

\section{Inhaltsübersicht}

Ehud Ben Zvi: Introduction

\section{A. Remembering and Forgetting in the Collection of Prophetic Books}

Ehud Ben Zvi: Remembering the Prophets through the Reading and Rereading of a Collection of Prophetic Books in Yehud. Methodological Considerations and Explorations - Jörg Jeremias: Remembering and Forgetting. »True« and »False« Prophecy - Sonya Kostamo: Remembering Interactions Between Ahaz and Isaiah in the Late Persian Period - Friedhelm Hartenstein: YHWH's Ways and New Creation in Deutero-Isaiah - Christina Ehring: YHWH's Return in Isaiah 40:1-11* and 52:7-10. Preexilic Cultic Traditions of Jerusalem and Babylonian Influence - Christoph Levin: »Days Are Coming. When It Shall No Longer Be Said«. Remembering and Forgetting in the Book of Jeremiah - William Morrow: Memory and Socialization in Malachi 2:173:5 and 3:13-21

\section{B. Remembering and Forgetting in Other Ancient Israelite Corpora}

Kåre Berge: The Anti-Hero as a Figure of Memory and Didacticism in Exodus. The Case of Pharaoh and Moses - Diana Edelman: Exodus and Pesach-Massot as Evolving Social Memory - Urmas Nõmmik: Remembering a Memorable Conversation. Genesis 18:22b-33 and the Righteous in the Persian Period - Michael Hundley: The Way Forward is Back to the Beginning. Reflections on the Priestly Texts - Hermann-Josef Stipp: Remembering Josiah's Reforms in Kings - Juha Pakkala: Selective Transmission of the Past in Chronicles. Jehoiada's Rebellion in 2 Kings 11 and 2 Chronicles 22:10-23:21 - Zhenhua (Jeremiah) Meng: Remembering Ancestors. A Levitical Genealogy in Yehud and the Bohai Gaos Genealogy of Gao Huan Judith Gärtner: From Generation to Generation. Remembered History in Psalm 78 - Bob Becking: Memory and Forgetting in and on the Exile. Remarks on Psalm 137 - Reinhard Müller: »Forgotten« by Yahweh. A Mental Image of Human Suffering and Its Function in »Exilic« Laments - James R. Linville: Lest We Forget Our Sins. Lamentations, Exilicism and the Sanctification of Disjunction

\section{Further Methodological Conclusions}

Francis Landy: Notes Towards a Poetics of Memory in Ancient Israel

Ehud Ben Zvi Born 1951; Professor (History \& Classics) at the University of Alberta; has served and serves as chair of program units/research programmes at the Society of Biblical Literature and the European Association of Biblical Studies ; founder and general editor of the Journal of Hebrew Scriptures and former president of the Canadian Society of Biblical Studies.

Christoph Levin Geboren 1950; 1998 bis zu seiner Emeritierung 2016 Professor an der Ludwig-Maximilians-Universität München; Mitglied der Akademie der Wissenschaften zu Göttingen und der Finnischen Akademie der Wissenschaften; 201013 Präsident der International Organization for the Study of the Old Testament (IOSOT).

Jetzt bestellen:

https://mohrsiebeck.com/buch/remembering-and-forgetting-in-early-second-temple-judah-9783161521348?no_cache=1 order@mohrsiebeck.com

Telefon: $+49(0) 7071-923-17$

Telefax: $+49(0) 7071-51104$ 